\title{
IS THERE A ROLE FOR PASSIVE SMOKING IN CERVICAL NEOPLASIA- A STUDY
}

\author{
S. Dhanyasree1, G. Ajay Kumar², Suneetha Rani Patro ${ }^{3}$, P. Anila Sunandini', Shaik Asha ${ }^{5}$, S. S. Amrutha Bindu', K. Swetha Naidu 7 , \\ Gowthami ${ }^{8}$
}

${ }_{1}^{1}$ Assistant Professor, Department of DVL, King George Hospital, Vishakhapatnam. ${ }^{2}$ Assistant Professor, Department of DVL, King George Hospital, Vishakhapatnam. 3 Postgraduate Student, Department of DVL, King George Hospital, Vishakhapatnam. ${ }^{4}$ Professor, Department of DVL, King George Hospital, Vishakhapatnam.

5 Postgraduate Student, Department of DVL, King George Hospital, Vishakhapatnam. ${ }^{6}$ Postgraduate Student, Department of DVL, King George Hospital, Vishakhapatnam. 7 Postgraduate Student, Department of DVL, King George Hospital, Vishakhapatnam. ${ }^{8}$ Postgraduate Student, Department of DVL, King George Hospital, Vishakhapatnam. ABSTRACT

\section{BACKGROUND}

Many proved studies link active cigarette smoking to cervical neoplasia, but very less information and evidence is known about the role of passive smoking and its effect on cervix and its epithelium. The main aim and objective of our study is to examine household passive smoke exposure and its role in development of cervical neoplasia.

\section{MATERIALS AND METHODS}

Our study included 100 women visiting outpatient STD Clinic, King George Hospital, Visakhapatnam in the months of July and August 2017. Out of 100 randomly selected women 50 women were non-smokers but exposed to passive smoking and another 50 women were non-smokers and not exposed to passive smoking. All of them were subjected to Pap smear testing. Chi-square test and ' $p$ ' values have been calculated.

Study Design- This is an observational, descriptive, cross-sectional study done at a single point of time by assessing Pap smear tests in various categories of selected women.

Study Setting- The study was conducted in hundred women attending the STD Clinic of DVL Department, King George Hospital, Visakhapatnam, Andhra Pradesh, India.

\section{RESULTS}

Out of 100 women 50 women who were exposed to passive smoking 6 had neoplasia and 50 women who were not exposed to passive smoking 2 had cervical neoplasia. In those exposed to passive smoking, the percentage of people who contracted cervical neoplasia was $12 \%$ and those among not exposed was $4 \%$. Chi-square value was 2.17 . Our 'p' value was 0.14 , which was not significant.

\section{CONCLUSION}

The associations were in the direction of increased risk. Though the 'p' value is not significant, yet the results of this study shows that there is increased cases of cervical neoplasia in passive smokers.

\section{KEYWORDS}

Passive Smoking, Cervical Cancer, Cervical Intraepithelial Neoplasia, Women, Tobacco Smoke Pollution, Life Partner Smoking.

HOW TO CITE THIS ARTICLE: Dhanyasree S, Kumar GA, Patro SR, et al. Is there a role for passive smoking in cervical neoplasia- a study. J. Evolution Med. Dent. Sci. 2018;7(06):779-782, DOI: 10.14260/jemds/2018/177

\section{BACKGROUND}

Cervical cancer is the fourth most commonly diagnosed cancer in women worldwide, 18/100,000 women per year contract the disease in developing countries and a disproportionate amount of women die because of this disease.[1] Persistent genital infection with oncogenic human papillomavirus (HPV) appears to be the most important cause of cervical cancer, $[2,3,4,5]$ but despite HPV's high

'Financial or Other Competing Interest': None.

Submission 02-12-2017, Peer Review 25-01-2018,

Acceptance 31-01-2018, Published 05-02-2018.

Corresponding Author:

Dr. G. Ajay Kumar,

Flat No. 503,

Arka Apartments, D. No. 15-12-17,

Krishna Nagar, Maharanipet,

Vishakhapatnam.

E-mail: ajaykumargummalla@gmail.com

DOI: $10.14260 /$ jemds $/ 2018 / 177$ prevalence (approximately $12.5 \%$ of women) ${ }^{[6]}$ smoking and other factors play an important role. The role of HPV infection in the causation of cervical cancer has raised the possibility that cigarette smoking could act as a cofactor that promotes progression of cervical carcinogenesis. ${ }^{7,8}$ The evidence now shows active cigarette smoking is causally associated with cervical cancer.

But less literature is available for the potential link between passive smoking and the development of cervical neoplasia. Cotinine, a nicotine metabolite, is present in measurable concentrations in the cervical mucus of active cigarette smokers.9,10 The presence of cotinine in cervical mucus of non-smoking women who are passively exposed to smoke from cigarettes makes it reasonable to postulate that passive smoking can contribute to carcinogenesis through the same potential pathways as active smoking including genotoxic and immunomodulatory effects. ${ }^{11,12}$ These effects could be manifested, for example through tobacco-specific Nnitrosamines. ${ }^{13}$ 
Altered local cervical cytokine profiles ${ }^{14}$ and altered immune cell infiltrates in the cervix of women with cervical dysplasia. 15,16

Determination of role of passive smoking to the risk of cervical cancer provides potential role of cigarette smoke in cervical cancer. Passive cigarette smoke is potentially modifiable and can be implied for strategies to prevent cervical cancer. The results of several case control and crosssectional studies indicate that women married to smokers experience a higher risk of cervical neoplasia than women married to non-smokers. ${ }^{17-21}$ In a prospective cohort study in Japanese women who never smoked, the relative risk of cervical cancer in those who were married to a smoker compared with those who were married to a non-smoker was 1.1 with wide $95 \%$ confidence limits $(0.3,4.5)$, because this result was based on only 9 cases of cervical cancer. ${ }^{22}$ To address this paucity of evidence, we evaluated influence of passive cigarette smoking on the risk of developing cervical neoplasia.

\section{Study Design}

This is an observational cross-sectional study done at a single point of time by assessing Pap smear tests in various categories of selected women.

\section{MATERIALS AND METHODS}

We selected a total of 100 women attending the STD clinic, KGH Hospital, Visakhapatnam, Andhra Pradesh, India in the months of July and August 2017.
1. The women were in the age group from 20 - 59 years.

2. Out of 100, exposed group were 50 women non-smokers, but exposed to tobacco smoke (partner is a smoker).

3. Out of 100 , unexposed group were 50 women nonsmokers and not exposed to household smoking.

4. The exposure- women who are exposed to tobacco smoke, i.e. passive smoking due to household exposure or partner smoking were those where the person is smoking at least 10 cigarettes per day (1 pack) since 5 years.

We excluded other confounding variables like tobacco chewing, multiple sexual partners (high-risk behaviour). The Papanicolaou test method of cervical screening was done on these 100 patients to detect pre-cancerous and cancerous changes in cervical epithelium. We have calculated the chisquare values and ' $p$ ' values to know the significance of our study. Out of 50 exposed group women, on pap smear test the reports showed 6 women had squamous cell carcinoma, 1 women had intraepithelial neoplasia, 22 had cervicitis of different types, 8 had just different complaints of per vaginal discharge and remaining had otherwise normal pap smear reports. In those exposed to passive smoking the percentage of people who contracted cervical neoplasia was $12 \%$ and those among not exposed was $4 \%$. As it was an observational, descriptive, cross-sectional study, we expressed our results in increased percentages which proves significant role of passive smoking in cervical neoplasia.

\section{RESULTS}

\section{Exposed Group}

\begin{tabular}{|c|c|c|c|}
\hline SI.no & PAP smear suggestive of & Other rem arks & $\begin{array}{l}\text { Number of } \\
\text { persons }\end{array}$ \\
\hline 1. & Squamous cell carcinoma & & 3 \\
\hline 2. & Atypical SCC & & 2 \\
\hline 3. & Carcinoma cervix & & 1 \\
\hline 4. & IEN- introe pithelial neo plasia & & 1 \\
\hline 5. & Papillary endocervicitis & & 10 \\
\hline 6. & Non specific endocervicitis & & 10 \\
\hline 7. & Infla mm atory endocervitis & & 1 \\
\hline 8. & Reactive changes with PMN le vo ocytes & & 1 \\
\hline 9. & no significant changes & Bacterial vaginosis & 1 \\
\hline 10. & II & Erosions, green discharge & 1 \\
\hline 11. & II & White discharge & 2 \\
\hline 12. & II & Mucoid discharge & 4 \\
\hline 13. & II & Healthy cx, no discharge & 13 \\
\hline
\end{tabular}

\section{Unexposed Group}

\begin{tabular}{|c|c|c|c|}
\hline st.no & PAP smear suggestive of & Other remarks & $\begin{array}{l}\text { Number of } \\
\text { persons }\end{array}$ \\
\hline 1. & squamous cell carcinoma & & 2 \\
\hline 2. & Atypicalsce & & 0 \\
\hline 3. & Corcinomacervix & & 0 \\
\hline 4. & IEN-introepithelial neoplasio & & 1 \\
\hline 5. & Papillary endocervicitis & & 2 \\
\hline 6. & Non specific endocervicitis & & 4 \\
\hline 7. & Inflammatory endocervit is & & 1 \\
\hline 8. & Reactive changes with PMN leucocytes & & 1 \\
\hline 9. & no significant changes & Bacterial vaginosis & 0 \\
\hline 10. & ॥ & Erosions, green discharge & 4 \\
\hline 11. & II & White discharge & 14 \\
\hline 12. & ॥ & Mucoid discharge & 11 \\
\hline 13. & ॥ & Healthy ox, no discharge & 10 \\
\hline
\end{tabular}




\begin{tabular}{|l|l|l|l|}
\hline & $\begin{array}{l}\text { Cervical } \\
\text { neoplasia }\end{array}$ & $\begin{array}{l}\text { Normal pap } \\
\text { smear }\end{array}$ & TOTAL \\
\hline EXPOSED & 6 & 44 & 50 \\
\hline UNEXPOSED & 2 & 48 & 50 \\
\hline TOTAL & 8 & 92 & 100 \\
\hline
\end{tabular}

Chi-square value $=2.17, \mathrm{P}$ value $=0.14$ (not significant $)$

\section{DISCUSSION}

This study of passive smoking on the risk of cervical neoplasia is unique in many aspects. Our study showed an increased percentage of cervical neoplasia in those who are exposed to passive smoking. In those exposed to passive smoking, the percentage of people who contracted cervical neoplasia was $12 \%$ and those among not exposed was $4 \%$. Chi-square value is 2.17 , ' $p$ ' value is 0.14 . In our study though ' $p$ ' value is not significant, it has shown an increased incidence of cervical neoplasia in passive smokers. As it was an observational, descriptive, cross-sectional study, we expressed our results in increased percentages which proves significant role of passive smoking in cervical neoplasia. Winkelstein first hypothesised in 1977 that smoking could be a risk factor for cervical cancer. Exposure to passive smoking was not a suspected risk factor in the 1960s, so it is rare for a cohort study initiated during that era to have the capacity to examine passive smoking. The major strengths of our study were the use of similar questionnaires across individual studies, such that important risk factors could all be adjusted in the same way. The results of the present study thus corroborate previous evidence documenting an association between role for passive cigarette smoking as a risk factor for cervical neoplasia. A major deficiency was the lack of measurement of passive smoke exposure outside the home. The proportion of women working outside of the home increased during the study periods, ${ }^{22}$ likely diminishing the importance of household passive smoke exposure with the passage of time. We also took into consideration some confounding variables such as number of sexual partners, parity and other sexually transmitted diseases that reflect potential exposure to and infection with oncogenic strains of human papillomavirus. In the study, we evaluated that passive smoking is also associated with cervical intraepithelial neoplasia (CIN) II and CIN III. The results of the study by Slattery and Cornelia Trimble ${ }^{23}$ et al provide prospective data suggesting that passive smoking is also associated with increased risk of cervical neoplasia. The adjusted relative risks were 2.1 and 1.4 in the year in 1963 and 1975 cohorts in Trimble et al. In the study of Rui Mei Feng et al, passive smoking had a slightly increased risk on the HPV infection with adjusted Odds Ratio 1.11 (1.00 - 1.24), but no statistical association was observed between passive smoke exposure and CIN2+. In the study conducted by Zeng XT et al, the results showed that women who never smoke but exposed to smoking experience a $73 \%$ increase in risk of cervical cancer compared with non-exposed women $(\mathrm{OR}=$ $1.73, \mathrm{p}<0.001$ ).

\section{CONCLUSION}

The associations were in the direction of increased risk. In those exposed to passive smoking, the percentage of people who contracted cervical neoplasia was $12 \%$ and those among not exposed was $4 \%$. Chi-square value is 2.17 . Our ' $p$ ' value is 0.14. The results of this cross-sectional study shows increased percentage of cervical neoplasia in people with passive smoking. As passive smoking is a modifiable entity, necessary steps should be taken to prevent cervical cancer.

\section{REFERENCES}

[1] Arbyn M, Castellsagué X, de Sanjosé S, et al. Worldwide burden of cervical cancer in 2008. Ann Oncol 2011;22(12):2675-86.

[2] Schiffman MH, Bauer HM, Hoover RN, et al. Epidemiologic evidence showing that human papillomavirus infection causes most cervical intraepithelial neoplasia. J Natl Cancer Inst 1993;85(12):958-64.

[3] Walboomers JM, Jacobs MV, Manos MM, et al. Human papillomavirus is a necessary cause of invasive cervical cancer worldwide. J Pathol 1999;189(1):1219.

[4] Vaccarella S, Franceschi S, Herrero R, et al. Sexual behavior, condom use and human papillomavirus: pooled analysis of the IARC human papillomavirus prevalence surveys. Cancer Epidemiol Biomarkers Prev 2006;15(2):326-33.

[5] IARC Working Group on the Evaluation of Carcinogenic Risks to Humans Human papillomaviruses. IARC Monogr Eval Carcinog Risks Hum 2007;90:1-636.

[6] Vaccarella S, Herrero R, Snijders PJ, et al. Smoking and human papillomavirus infection: pooled analysis of the International Agency for Research on Cancer HPV Prevalence Surveys. Int J Epidemiol 2008;37(3):53646.

[7] Ho GYF, Kadish AS, Burk RD, et al. HPV 16 and cigarette smoking as risk factors for high-grade cervical intraepithelial neoplasia. Int J Cancer 1998;78(3):281-5.

[8] Olsen AO, Dillner J, Skrondal A, et al. Combined effect of smoking and human papillomavirus type 16 infection in cervical carcinogenesis. Epidemiology 1998;9(3):346-9.

[9] McCann MF, Irwin DE, Walton LA, et al. Nicotine and cotinine in the cervical mucus of smokers, passive smokers and nonsmokers. Cancer Epidemiol Biomarkers Prev 1992;1(2):125-9.

[10] Poppe WA, Peeters R, Daenens P, et al. Tobacco smoking and the uterine cervix: cotinine in blood, urine and cervical fluid. Gynecol Obstet Invest 1995;39(2):110-14.

[11] Szarewski A, Jarvis MJ, Sasieni P, et al. Effect of smoking cessation on cervical lesion size. Lancet 1996;347(9006):941-3.

[12] Prokopczyk B, Cox JE, Hoffmann D, et al. Identification of tobacco-specific carcinogen in the cervical mucus of smokers and nonsmokers. J Natl Cancer Inst 1997;89(12):868-73. 
[13] Eppel W, Worda C, Frigo P, et al. The influence of cotinine on interleukin 6 expression in smokers with cervical preneoplasia. Acta Obstet Gynecol Scand 2000;79(12):1105-11.

[14] Szarewski A, Maddox P, Royston P, et al. The effect of stopping smoking on cervical Langerhans' cells and lymphocytes. BJOG 2001;108(3):295-303.

[15] Poppe WAJ, Ide PS, Drijkoningen MPG, et al. Tobacco smoking impairs the local immunosurveillance in the uterine cervix. An immunohistochemical study. Gynecol Obstet Invest 1995;39(1):34-8.

[16] Buckley JD, Harris RW, Doll R, et al. Case-control study of the husbands of women with dysplasia or carcinoma of the cervix uteri. Lancet 1981;2(8254):1010-5.

[17] Hellberg D, Valentin J, Nilsson S. Smoking and cervical intraepithelial neoplasia. An association independent of sexual and other risk factors? Acta Obstet Gynecol Scand 1986;65(6):625-31.

[18] Slattery ML, Robison LM, Schuman KL, et al. Cigarette smoking and exposure to passive smoke are risk factors for cervical cancer. JAMA 1989;261(11): 1593-8.
[19] Coker AL, Bond SM, Williams A, et al. Active and passive smoking, high-risk human papillomaviruses and cervical neoplasia. Cancer Detect Prev 2002;26(2):121-8.

[20] Tay SK, Tay KJ. Passive cigarette smoking is a risk factor for cervical neoplasia. Gynecol Oncol 2004;93(1):116-20.

[21] Nishino Y, Tsubono Y, Tsuji I, et al. Passive smoking at home and cancer risk: a population-based prospective study in Japanese non-smoking women. Cancer Causes Control 2001;12(9):797-802.

[22] Winkelstein W. Smoking and cancer of the uterine cervix: hypothesis. Am J Epidemiol 1977;106(4): 257-9.

[23] Trimble CL, Genkinger JM, Burke AE, et al. Active and passive cigarette smoking and the risk of cervical neoplasia. Obstet Gynecol 2005;105(1):174-81. 